\title{
THE IMPORTANCE OF DIGITAL RESOURCES IN THE INSTRUCTION OF MODERN LATVIAN LANGUAGE AND LITERATURE ${ }^{1}$
}

\author{
Anna Vulāne \\ University of Latvia, Latvia \\ Elita Stikute \\ University of Latvia, Latvia
}

\begin{abstract}
The aim of the article is to provide an insight into the digital resources used in teaching Latvian language and literature, and to analyse the results of supplementing the syllabus with material from the digital dictionary "e-PUPA" in order to facilitate learners' interest in the varieties of the Latvian language, and of an in-depth study of literature through the use of various digital resources aimed to develop learners' digital literacy. The research was conducted for three academic years (2017-2019) in Riga Centre Language School (Rĩgas Centra humanitārā ǵimnāzija), involving 98 learners (total) from Grade 10. In order to achieve the intended outcome, a range of exercises and assignments were prepared.

Work with these assignments encouraged the learners' critical and creative thinking, as well as their linguistic, communicative and digital literacy. It also helped them to perceive language units in a complex and functional way; strengthened the inter-subject link; enhanced their skills of text composition, research and cooperation; and encouraged selfguided learning.

Research results proved that the material included in the digital dictionary "e-PUPA" was useful in studying the Latvian language and literature. It helps learners to appreciate the richness, diversity and beauty of the Latvian language. Usage of the "e-PUPA" dictionary allowed the learners to deepen their knowledge in all sub-branches of linguistics and to expand their vocabulary. It also provided them with linguistically correct information about the phonetic, derivative and semantic structure of words, their grammatical features, etymology, functional environment, collocations, onymic systems, cultural labels etc., as well as their application in the regional dialects of Latvian, in Latgalian written language, and in foreign languages. Besides, the folklore material and excerpts from fiction and scientific works and publications, used to illustrate the meaning of certain lexical units, as well as various culturally historical facts and works of artenhanced learners' interest in the nations' world view reflected in the language.
\end{abstract}

Keywords: teaching/learning Latvian language and literature, digital resources, digital dictionary "e-PUPA". 


\section{Introduction}

The rapid digitalisation of information has created new and previously unknown challenges in education. Both the educational establishments and the wider society have to accept the fact that information and communication technologies play a more and more significant role in everyday life; that new software and hardware is constantly being developed and the mobile devices are becoming more advanced. This allows people to digitally capture and share information in graphemic, audio or video format. Students at schools, universities etc. are not only able to participate in classroom activities in person, but also to record them, take photos of the relevant materials, organise group conferences, receive private lessons and consultations and submit assignments, at the same time being in another part of the world.

People tend to get accustomed to things that make their life easier. Therefore it is no surprise that the millennials see the internet and the materials available online as their principal source of information. It is therefore important to provide the learners with digital study materials, reference materials and digitised literary works alongside traditional books, thereby ensuring that the digital space contains relevant and highquality resources. Carefully prepared digital materials are of great help to schoolteachers and university lecturers, as learners find them easily accessible and convenient to use.

The need to develop learners' digital literacy is closely linked with the emergence of the information society which replaced the industrial society around the turn of the centuries. Edvinns Karnitis notes that societal systems change only when the accumulated knowledge becomes restricted by the current model and when the existing model of social relations prevents further growth; when the knowledge level in the old system is sufficiently high to allow the society to move to the next stage of development. It is exactly at that point when all the necessary prerequisites give rise to new work methodology and relations, and to a new societal and political organisation (Karnitis 2004: 83).

At the beginning of this century, the accumulated knowledge base in pedagogy, digitalisation theory and practice, linguistics and literary theory had reached such a level and quality that the transition from the classical education triangle model (see Picture 1) to the new multimedial model was not only logical but also necessary for the knowledge society to evolve. 


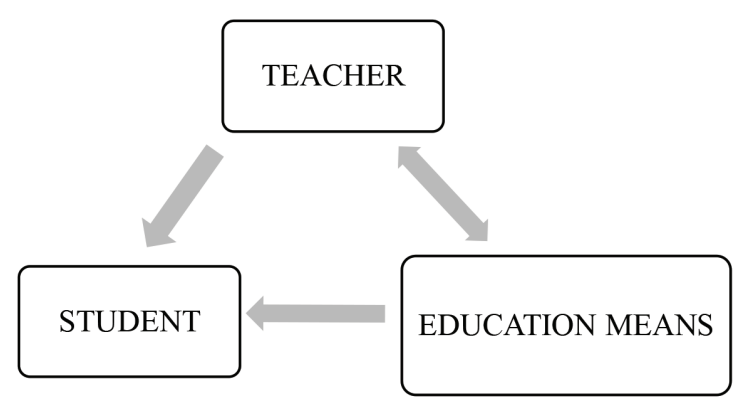

Picture 1. Classical education triangle model

Some characteristics of this model include the learners' ability to actively engage in the learning process; the acquisition of skills and knowledge not only through materials provided by teachers and the curriculum, but also through cooperation and discussions with classmates, as well as from various academic resources, including digital ones (see Picture 2).

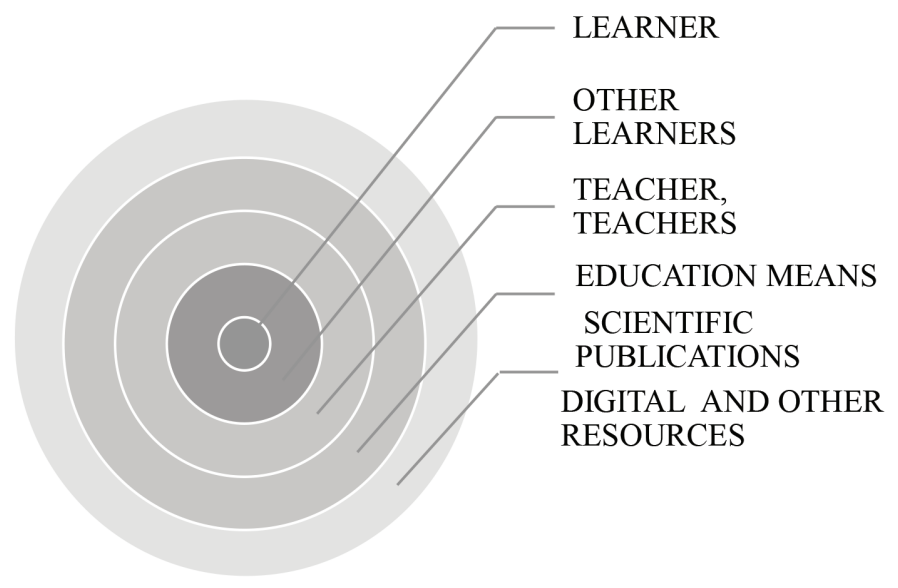

Picture 2. Multimedial model

\section{Aim of the Study}

The aim of the research was to understand the functionality and effectiveness of the newest digital resources (dictionary "e-PUPA", "Latvian Language Manual", "Map of Linguistics", educational tool "Olūteņš", and "Latgalian Spelling Tool") in the instruction of Latvian language and literature. This article provides brief information about each of these digital resources and the key conclusions on their usability. The article also details the practical experience of using the digital dictionary "e-PUPA". 


\section{Materials and Methods}

This research is largely based on Action Theory (Joas, Beckert, 2001), as well as on the findings of various researchers about the application of digital study resources (Daniela, Rubene, Goba, 2018; Daniela, Kalniņa, Strods, 2017; Dudareva, 2018; Brinkley, Dessants, Flamm, 1999), WEB evaluation (Kapoun, 1998), and the devepment of digital skills (Ferrari, 2013) in the study process.

The study combined the descriptive method and content analysis, and was conducted by the help of experiments and questionnaires.

Content analysis was used in order to:

- select relevant working material after the survey of 409 entries of the digital dictionary "e-PUPA". The main objective of this analysis was to understand (a) the specific features of lexemes in different dialects, and their role in developing the linguistic and socio-cultural competence of the learners, and (b) the functionality of using dialect maps for learning purposes,

- analyse the riddles and tales composed by the learners themselves, thus testing their perception of dialectal words and their functional characteristics.

Each academic year, 30 entries of the dictionary "e-PUPA" were chosen for the experiment and offered to the learners for analysis. Each of them then had to choose one entry and to fulfill the assigned tasks (see below). Every month, the work was organised in the following stages:

- assignment of tasks and classroom discussions,

- getting acquainted with the structure of the dictionary,

- analysis of Latvian folktales and riddles,

- independent research work (selecting and exploring a dictionary entry, analysis of the map, processing and structuring the obtained linguistic information),

- creative work (writing riddles and tales),

- presentation of the results in the classroom; peer review and selfreview with the help of a questionnaire.

Finally, the independent research work results were assessed and the questionnaire answers were analysed. On the whole, 98 learners were involved in the experiment over the course of three academic years.

\section{Digital Resources}

As mentioned previously, numerous tools have been created for implementation in the syllabi of teaching Latvian as a native or second language and the Latvian literature, in accordance with the standards agreed on in the project "Skola2030" (School2030). Among these tools, the most essential ones are are the digital dictionary "e-PUPA", "Latvian 
Language Manual", "Map of Linguistics", as well as the educational tool "Olūteñs" and the "Latgalian Spelling Tool".

In 2018, three of these resources - "Map of Linguistics", "Latvian Language Manual" and "Olūtenšs" - were completed, and in 2019 the development of a Latgalian spelling tool was began within the National Research Programme.

- "Map of Linguistics" (http://www.lingvistiskakarte.lv) is a digital database containing information on various events, individuals and places related to linguistics (see Picture 3). The map is showing the locations of the relevant events, birthplaces of people etc. All parts of the "Map of Linguistics" are interactive. Entries can be grouped according to persons, publications, events, places, or branches of linguistics. Besides that, the database also offers several tourism routes in Latvia with downloadable and printable overview maps.

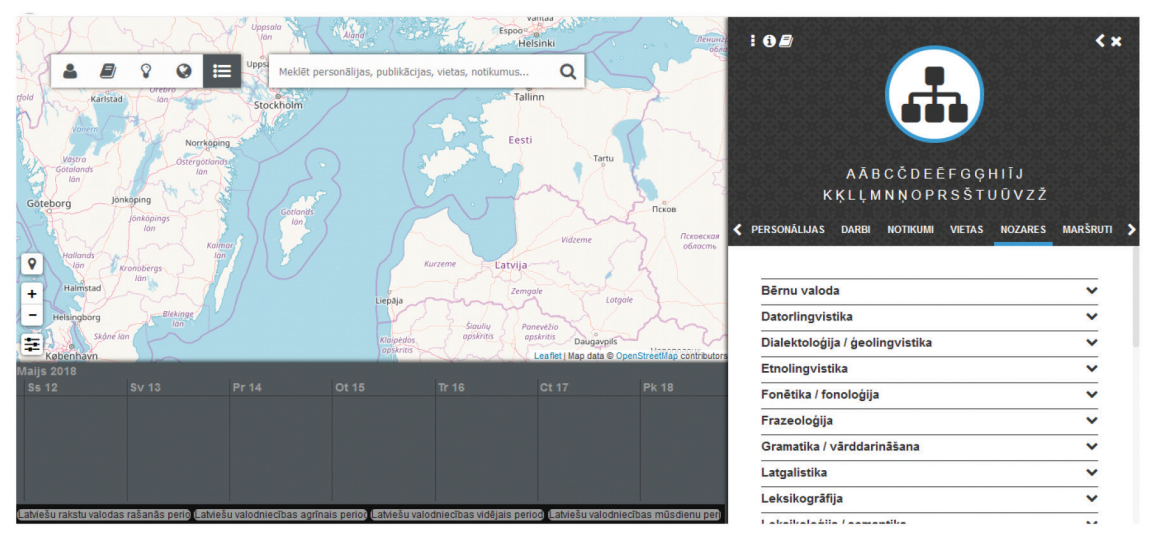

Picture 3. Map of Linguistics

- "Latvian Language Manual" (http://valodasrokasgramata.lv/) is an encyclopaedic collection; it is a multifunctional and informative digital educational tool on Latvian linguistics. It covers the main concepts of 26 branches and sub-branches of linguistics (containing over 1,500 entries or units). The material is compiled in two levels basic and advanced. It contains theory, exercises, test questions, audio materials and linguistic maps (see Picture 4). 


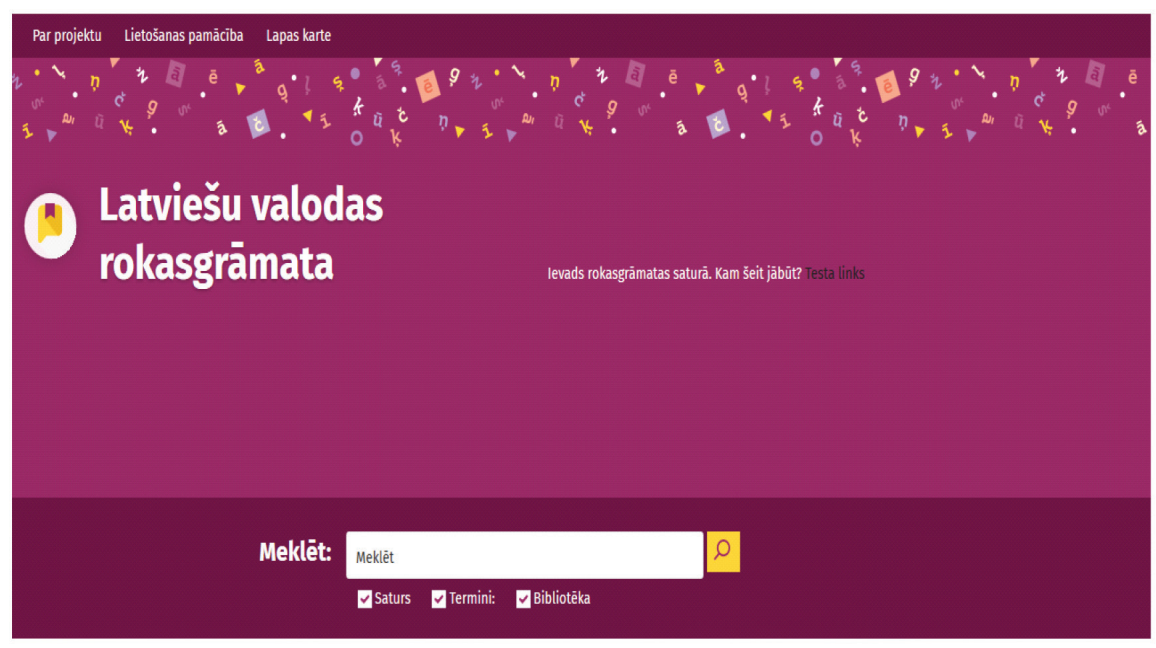

\begin{tabular}{|c|c|c|c|}
\hline Vispārigea valodnieciba & Fonêtika & Fonoloǵjja & Pareizruna (ortoepija) \\
\hline Gramatika & Morfèmika & Morfonoloǵija & Pareizrakstiba (ortogrātija) \\
\hline Värddarināšăana & Morfoloǵjja & Sintakse & Leksikoloǵija un semantika \\
\hline Terminoloğija & Onomastika & Frazeoloğija & Leksikografijja \\
\hline Tekstveide & stilistika & Valodniecibas vēsture & Sazinga \\
\hline Latgaliešu rakstu valoda & Dialektoloǵjia & Etnolingvistika & Datorlingvistika \\
\hline Korpuslingvistika & Sociolingvistika & & \\
\hline
\end{tabular}

Picture 4. Latvian Language Manual

- The Latvian language has two written traditions - Standard Latvian and written Latgalian. For the purpose of teaching written Latgalian and regional studies in Latgale, the educational tool "Olūteņs" https://visc.gov.lv/vispizglitiba/saturs/dokumenti/ metmat/olutens_ 4kl_mac_lidz.pdf; htps://visc.gov.lv/vispizglitiba/saturs/dokumenti/ metmat/olutens_4kl_met_\%20ieteikumi.pdf) for Grade 4 was elaborated (see Picture 5). It can also be successfully employed outside Latgale to learn more about this written tradition. The Latgalian spelling tool which is currently under development, will further support this.

- The work on compiling the multifunctional digital dictionary "e-PUPA" (see Picture 6) was began in 2011 (http://epupa.valoda. lv/). The dictionary contains word definitions, illustrations, dialect maps, as well as several articles by linguists, methodological instructions for teachers, and worksheets to be used in the study process. 


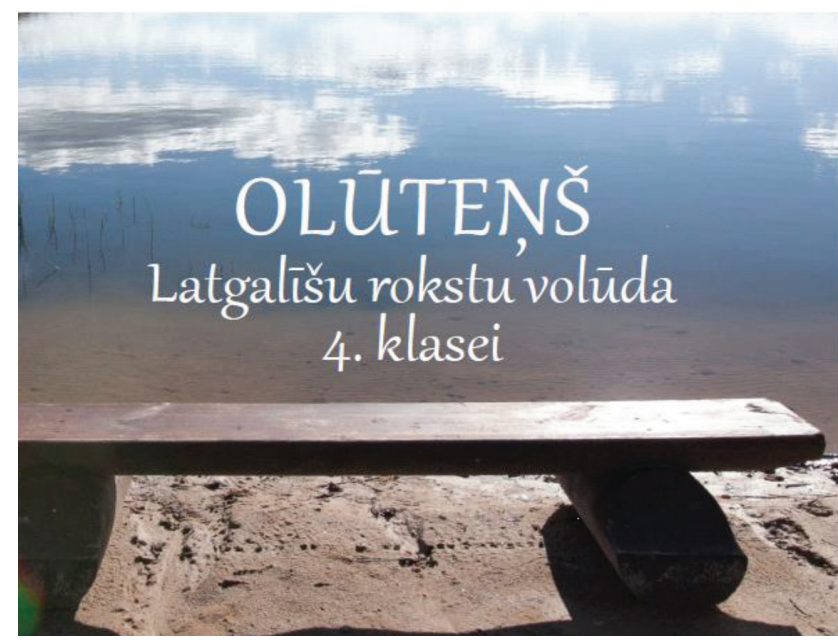

Picture 5. Educational tool "Olūteņš"

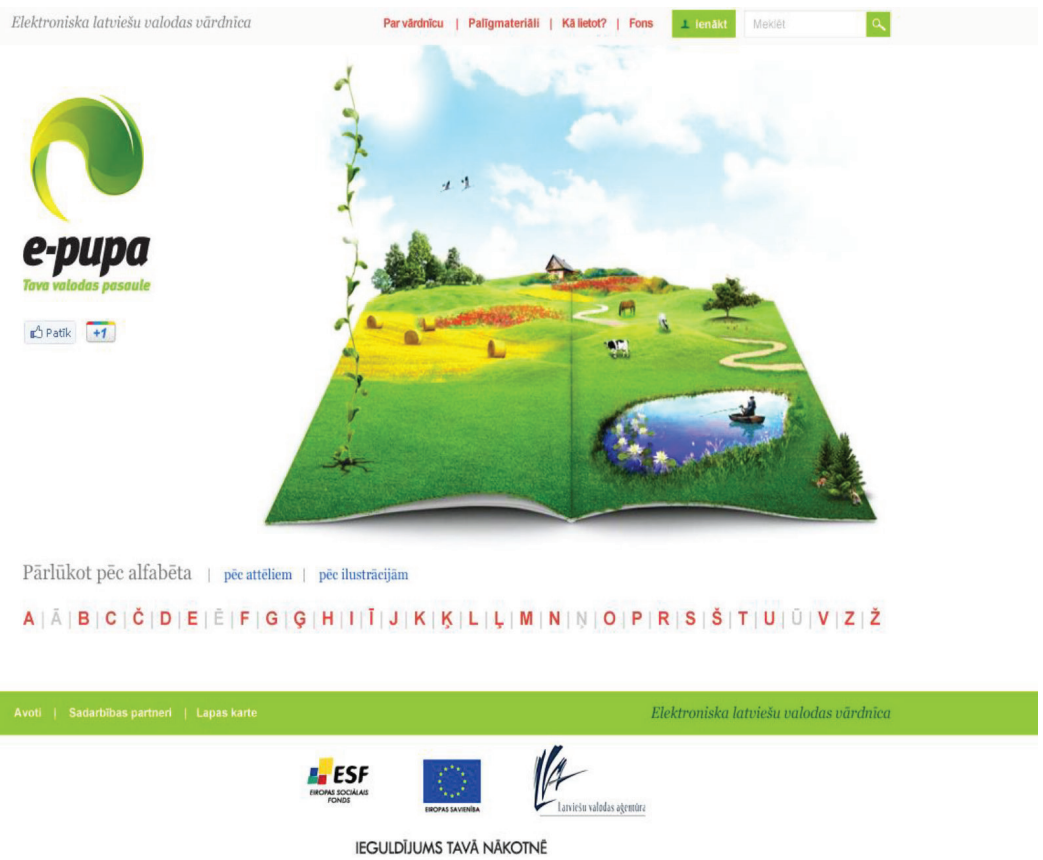

Picture 6. Multifunctional digital dictionary "e-PUPA"

The scope of the entries is varied. There are full-scope entries (see Picture 7) consisting of 21 structural element covering approximately 40 pages (72,000 characters); medium-scope entries with up to 20 structural elements on approximately 20 pages (36,000 characters), and low-scope 
entries with up to 20 structural elements on approximately 4 pages $(7,200$ characters). The basic concept of the dictionary is the idea that every human is a biological, spiritual and social being. This is the reason for including copious and diverse material in the dictionary.

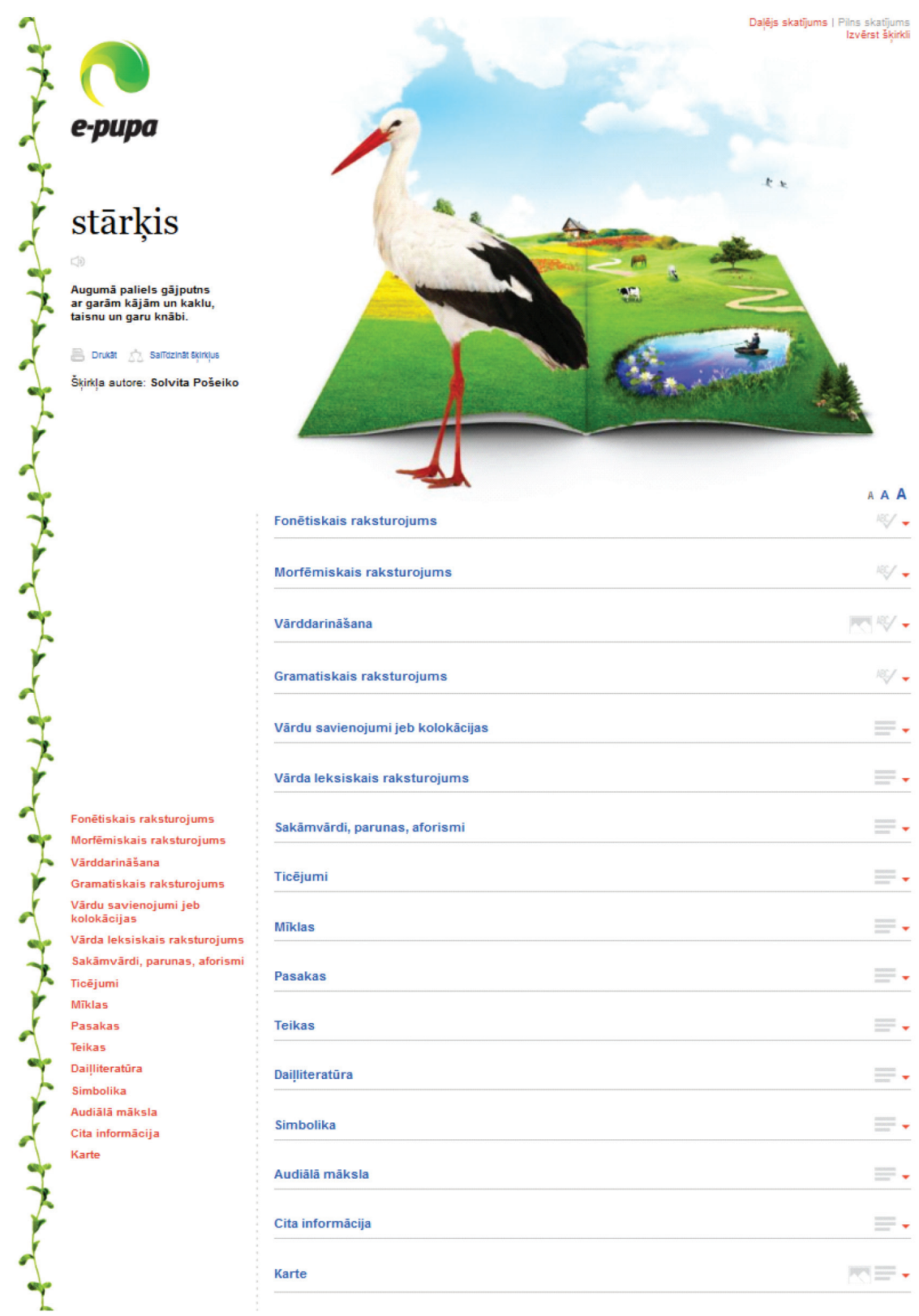

Picture 7. The structure of an entry (stārḳis 'stork') 
The dictionary can be used as a supplement in teaching not only language and literature, but also other subjects. Apart from improving the learners' proficiency of language and literature, it also encourages their integration skills and inquisitive interest. Furthermore, the dictionary material can also be used in universities for students of philology, translation studies and education sciences; in courses where Latvian is taught as second or foreign language; in other kinds of informal education, and also in academic research.

In order to help the learners to learn how to learn (Fadels, Bialika, Trilings, 2016), the teachers need to cooperate, to create an appropriate learning environment, and to encourage the creative and critical thinking of the learners (Fisher, 2005a; Fisher, 2005b; Stikute 2011), as well as their skills of cooperation and research. For this purpose, appropriate set of resources and linguo-didactic materials have to be developed.

Elaborating the new standards and programmes for teaching the Latvian language and literature in the beginning of the $21^{\text {st }}$ century, it became obvious that various easily accessible additional materials and resources would be necessary. The project "Skola2030" (School2030) of 2019, also emphasized the need to apply the possibilities and advantages of information technology and digital solutions in the education process, so that the learners would use digital resources not only for entertainment, but also for developing certain skills. These resources can help to acquire new knowledge, to enhance creativity and critical thinking, and to arrive to innovative learning solutions in the process (Daniela, Rubene, Goba, 2018, 3).

A vast array of digitalised material is already available for studying Latvian literature and the Latvian language. That includes websites containing scientific literature, study materials, texts and textbooks, dictionaries, encyclopaedias, power-point presentations, lectures and classroom notes. Digital study materials differ from the traditional materials in that they can be multi-modular, combining real, virtual and augmented study environment and thus they are a powerful tool for transforming the study process and enhancing the learning environment (Kirkwood, Price, 2014). At the same time, this situation also constitutes a problem. Overwhelming majority of these materials exist by themselves, meaning that they have not been integrated into the study curriculum and thus their application depends on the teacher's choice. Express interviews with learners (circa 500) of various subjects show that most teachers do not make use of the digital resources. The reasons for this, as explained by the teachers themselves, usually are the excessive workload as well as lack of knowledge and inability to include these materials in the study process. Therefore, a research was conducted during 2017-2019 to assess the ways 
of applying the newest digital resources in teaching work with the aim to improve the educational content and the communicative competence of learners of language and literature.

\section{Results}

Enhancement of the educational content was conducted during 20172019, every year offering the following exercises to Grade 10 learners in their Latvian language classes:

- introduction to and definition of various branches of linguistics with the help of the digital dictionary "e-PUPA",

- study of word meanings, monosemantic and polysemantic words and their semantic structure,

- work with dialect maps and dialectal words,

- study of phraseological units, expansion of vocabulary.

For example, in order to learn that a single concept can be expressed in different ways, the learners had to select and review a dialect map from the "Atlas of the Latvian Dialects" (Laumane 1999), which can be accessed via the digital dictionary "e-PUPA". As a next step, they had to study the vocabulary of a particular sub-dialect. In the process the learners:

- obtained a basic theoretical notion of a dialect and a sub-dialect by reading relevant research and listening to the materials provided by the teacher. Furthermore, they gained more detailed knowledge about the differences of Latvian dialects and sub-dialects, as well as an insight into the historical events, geographic environment and other factors that have influenced them;

- learned to interpret dialect maps and to understand map legends, as well as to identify various Latvian sub-dialects and to understand their vocabulary.

Having completed the review of a map, the learners had to choose a medium for presenting and visualising the acquired information (e.g. by drawing a map, a table, or a schematic diagram; see Picture 8). 


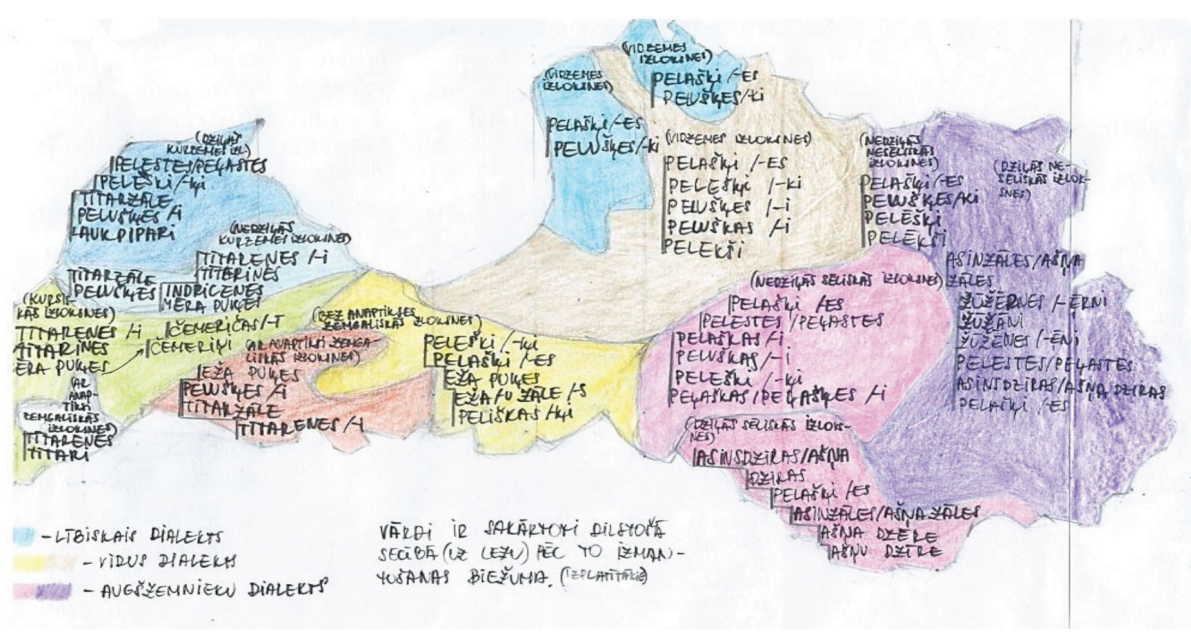

\begin{tabular}{|c|c|c|c|}
\hline \multicolumn{4}{|c|}{ Vārda stārkis izpēte } \\
\hline & Lībiskais dialekts & Vidus dialekts & Augšzemnieku dialekts \\
\hline Aists & & & Bērzpils \\
\hline $\begin{array}{l}\text { Bacans, } \\
\text { Bocjans }\end{array}$ & & & $\begin{array}{l}\text { Ezernieki, Malta, } \\
\text { Rundēni, Asūne, Istra }\end{array}$ \\
\hline Bačans & & & Kaunata \\
\hline Bočaks & & & Vilaka \\
\hline $\begin{array}{l}\text { Gandr/ } \\
\text { is, }-s\end{array}$ & & $\begin{array}{l}\text { Vainode, Nīgrande, } \\
\text { Aizvīkiki, Nīkrāce, Kaltēti }\end{array}$ & \\
\hline Kalests & & & Škilbēni \\
\hline Kaliusts & & & Vilaka \\
\hline Kḷikuns & & & Vilaka \\
\hline Poḷaks & & & Kaunata \\
\hline Stārgs & & & Sunākste \\
\hline Starka & Katvari, Lāde, Vainiži & $\begin{array}{l}\text { Plātere, Keipene, } \\
\text { Dauguli, Suntaži, Svitene }\end{array}$ & $\begin{array}{l}\text { Menggele, Vestiena, } \\
\text { Prauliena, Sarkani, }\end{array}$ \\
\hline Stārka & Bīrin̨i, Limbaži & Lēdurga, Mujāni & Pl̦avinas, Šāviena, \\
\hline Starks & $\begin{array}{l}\text { Svētciems, Rozēni, } \\
\text { Vitrupe, Dzirciems }\end{array}$ & $\begin{array}{l}\text { Birzgale, Dole, Ozolnieki, } \\
\text { Garoza, Liece }\end{array}$ & $\begin{array}{l}\text { Balvi, Mērdzene, } \\
\text { Bērzgale, Viesīte, Zalve }\end{array}$ \\
\hline Stārks & Engure, Usma & $\begin{array}{l}\text { Tērvete, Auri, Līvbērze, } \\
\text { Sātin̨i, Milzkalne Misa }\end{array}$ & Sunākste, Tirza \\
\hline Starkis & $\begin{array}{l}\text { Dundaga, Nogale, } \\
\text { Lauciene, Ainaži, Idus }\end{array}$ & $\begin{array}{l}\text { Jaunpils, Lestene, Tome, } \\
\text { Krape, Skrīveri, Ādaži }\end{array}$ & $\begin{array}{l}\text { Kaplava, Saliena, } \\
\text { Makašěni, Meirāni }\end{array}$ \\
\hline Storķis & $\begin{array}{l}\text { Stende, Laidze, Užava, } \\
\text { Mērsrags, Upesgrīva }\end{array}$ & & \\
\hline Sventelis & Cīrava, Valtaiki & & \\
\hline Svētainis & Rūjiena & Pampāli, Ruba, Kursīši, & \\
\hline Svēteklis & & Gatarta & \\
\hline Svētelis & $\begin{array}{l}\text { Zlēkas, Strazde, } \\
\text { Zentene, Lībagi, } \\
\text { Kuldīga, Padure }\end{array}$ & $\begin{array}{l}\text { Dzērbene, Veselava, } \\
\text { Cēsis, Drabeši, Grobiṇa }\end{array}$ & $\begin{array}{l}\text { Dignāja, Līvāni, Saikava, } \\
\text { L̦audoṇa, Mētriena }\end{array}$ \\
\hline Svētēlis & & Bārta, Nīca, Dunika, & \\
\hline Svētenis & & Bilska & \\
\hline
\end{tabular}




\begin{tabular}{|c|c|c|c|}
\hline \multicolumn{4}{|c|}{ Vārda stārkis izpēte } \\
\hline & Lībiskais dialekts & Vidus dialekts & Augšzemnieku dialekts \\
\hline Svētnesis & & Ceraukste & \\
\hline Svētputns & $\begin{array}{l}\text { Piltene, Ugāle, Padure, } \\
\text { Ziras, Jūrkalne }\end{array}$ & $\begin{array}{l}\text { Turlava, Rank,ki, } \\
\text { Rudbārži, Kurmāle }\end{array}$ & \\
\hline Svētulis & $\begin{array}{l}\text { Zlēkas, Valgale, } \\
\text { Zentene }\end{array}$ & Remte, Bērze, Zaḷenieki & Aizkraukle, Krustpils \\
\hline Štargs & & Sauka, Rite, Elkšņi & \\
\hline Štarka & & & $\begin{array}{l}\text { Barkava, Vīpe, Stirniene, } \\
\text { Atašiene }\end{array}$ \\
\hline Štarks & & & Āknīste, Bebrene, Nīcgale \\
\hline Štarḳis & & Sala & \\
\hline Tāks & & Sīpele & \\
\hline Tarks & Pāle & $\begin{array}{l}\text { Zālīte, Rembate, } \\
\text { Lielvārde, Baldone }\end{array}$ & \\
\hline Tārks & & Lēdmane & \\
\hline Žubure & & & Barkava, Viḷāni \\
\hline Žugare & & & Atašiene \\
\hline Žugure & & & $\begin{array}{l}\text { Rudzēti, Preilii, Gaigalava, } \\
\text { Tilža, Lubāna }\end{array}$ \\
\hline Žūrējs & & & Škíilbēni \\
\hline
\end{tabular}

Picture 8. Examples of learners' work

Finally, the learners had to fulfill a creative task: to write three interesting, witty and challenging riddles about the researched words. They also had to invent a tale of origin of a particular dialectal word. Assessment of the learners' work led to the following results and conclusions:

\begin{tabular}{|l|c|c|c|c|c|}
\hline \multicolumn{2}{|l|}{ The analysis of dialect maps } & \multicolumn{2}{|c|}{$\begin{array}{c}\text { Interpretation of dialectal } \\
\text { words (\%) }\end{array}$} & \multicolumn{2}{c|}{ Genre (\%) } \\
\hline 98 works & $\%$ & $\begin{array}{c}\text { riddles } \\
(130 \text { works) }\end{array}$ & $\begin{array}{c}\text { tales of origin } \\
\text { (98 works) }\end{array}$ & riddle & $\begin{array}{c}\text { tale of } \\
\text { origin }\end{array}$ \\
\hline Excellent & 72 & 17 & 29 & 81 & 78 \\
\hline Well & 25 & 74 & 55 & 13 & 19 \\
\hline Average & 3 & 8 & 16 & 5 & 3 \\
\hline Not done & 0 & 1 & 0 & 1 & 0 \\
\hline
\end{tabular}

In order to find out the learners' opinion about the usability and effectiveness of the newest digital resources in learning Latvian language and literature, a questionnaire was compiled. It included the following questions: 
1. Can you name 3 to 5 new interesting facts that you learned by researching a particular dialectal word?

2. What else did you learn from this experiment/research?

3. What did you understand when fulfilling the assignments?

4. What thoughts did this research provoke?

5. What difficulties did you encounter during the experiment/research?

Summing up all the feedback of the experiment, it was concluded that the use of digital resources helped to improve and train various skills, namely:

- skills of researchand analysis, the ability to structure information and to draw relevant conclusions,

- critical thinking, i.e. the ability to rely on scientifically trustworthy sources, as well as to critically examine one's own and the others' work,

- written and verbal communication skills (including the composition of a formal message, as several pupils submitted their assignments to the teacher by e-mail via the e-classroom system,

- proficiency of using various digital resources and media. Several participants of the experiment confessed to having difficulties with this, as they found it easier to work from paper copies. Several learners admitted that it was difficult to use digital maps. These instances showed that school learners are not yet familiar with this kind of research work.

The learners later applied the experience gained from the abovedescribed research in their literature classes as well - for instance, when analysing the role of dialectal words in a poem or prose text. The dictionary was also used to discuss the attitude of our ancestors towards various realia and the way their worldview is reflected in language and in folklore. Another important and significant outcome of this experiment was the fact that some learners became interested in developing dictionary entries of their own. For instance, one student elaborated an entry with the headword "Wedding" as the result of her project which later won the 2nd place in a nation-wide competition of school research projects in 2017.

By using "e-PUPA" and other digital resources, learners were able to develop self-guided learning skills, as they had to complete the assignments independently, including decisions on formatting and presenting their work. They also improved their responsibility and time management ability. The experimental study also helped to develop collaboration skills, as those learners who were absent from classes had to obtain information and advice from their peers as well, not only from their teacher.

When inventing and composing their own riddles and legends, the learners not only improved their knowledge of folklore and literature, 
but also developed their creative thinking. They agreed that they had fun when doing this task where they could apply their creativity.

On the whole, this educational project improved the so-called intersubject link (involving such subjects as geography, history of culture, and regional studies), as well as the ability to relate the acquired knowledge to real life. For example, several learners commented on certain dialectal features or vocabulary that they remembered having heard in their grandparents' native region.

\section{Conclusions}

The research lead to the following conclusions:

- the use of digital linguistic resources in the educational process depends on the teachers' awareness about their existence, as well as their desire to diversify the content of the curriculum and to offer new materials to their learners,

- the use of the digital dictionary, map and manual helps to improve learners' knowledge in all sub-branches of linguistics, to expand their vocabulary, and to obtaining linguistically correct information about the phonetic and semantic structure of words, their grammatical features, etymology, functional environment, collocations, onymic systems,

- the educational tool "Olūtenşs" can be used in schools not only in Latgale but also elsewhere in Latvia in order to get acquainted with the Latgalian written language and cultural values. In addition, the "Latgalian Spelling Tool" can help to improve text-building skills,

- the resources "e-PUPA" and "Map of Linguistics" are useful not only for learning Latvian language and literature, but also in such subjects as foreign languages, history, cultural studies, geography etc.,

- all the above-mentioned digital resources can be successfully used as methodological aid for teachers, and also as academically correct sources of information and tools for developing linguo-didactic skills,

- the main advantage of digital resources is their availability at any time and place, and the possibility to obtain the necessary information quickly and easily. The use of IT promotes the differentiation and diversification of the study process through innovative means. 


\section{References}

Brinkley, A., Dessants, B., Flamm, M. (s. a.). Using Electronic Resources for Teaching an Excerpt from The Chicago Handbook for Teachers: A Practical Guide to the College Classroom. Retrieved from: http://www.press.uchicago.edu/Misc/Chicago/075125.html.

Daniela, L., Kalnina, D., Strods, R. (2017). An overview on effectiveness of technologyenhanced learning (TEL). International Journal of Knowledge Society Research. Vol. 8, Issue 1, pp. 79-81.

Daniela, L., Rubene, Z., Goba, L. (2018). Datu apkopojums un ārvalstu un Latvijas pieredzes analïze par digitālo mācību lìdzekḷu pieejamïbu un izmantošanu vispārējās izglìtỉbas mācību satura nodrošināšanai [Data collection and analysis of foreign and Latvian experience on the availability and use of digital teaching aids for general education curriculum]. Retrieved from: http://www.izm.gov.lv/images/statistika/petijumi/ Datuapkopojums-un-arvalstuun-Latvijas-pieredzes-analize-par-DML_2018.pdf (in Latvian).

Dudareva, I. (2018). Informācijas tehnolog̣ijas mācīšanās iedziḷinoties atbalstam [Information technology for deep learning support. In: Zane Olina et al. Mācišanās lietpratibai [Learning to Competence]. Rīga: Latvijas Universitāte, 189.-211. lpp. Retrieved from: https://www.siic.lu.lv/fileadmin/user_upload/lu_portal/projekti/siic/ Kolektiva_ monografija/Macisanas_Lietpratibai.pdf (in Latvian).

Elektroniska latviešu valodas vārdnica "e-PUPA" [Digital Dictionary of Latvian "e-PUPA"]. Retrieved from: http://epupa.valoda.lv/ (in Latvian).

Fadels, Č., Bialika, M., Trilings, B. (2016). Četru dimensiju izglitïba [Four-dimensional Education]. Retrieved from: https://app.soma.lv/book/pdf-reader/cetru-dimensijaizglitiba? page $=7 \&$ toc $=4686$ (in Latvian).

Ferrari, A. (2013). DIGCOMP: A Framework for Developing and Understanding Digital Competence in Europe. Luxembourg: Publications Office of the European Union. Retrieved from: http://publications.jrc.ec.europa.eu/repository/bitstream/ JRC83167/ lb-na-26035-enn.pdf.

Fišers, R. (2005a). Mācissim bèrniem mācīties [Teaching Children to Learn]. Rīga: RaKa. (in Latvian).

Fišers, R. (2005b). Mācīsim bērniem domāt [Teaching Children to Think]. Rīga: RaKa. (in Latvian).

Jansone, I., Vulāne, A. (Eds.) (2018). Latviešu valodas rokasgrāmata [Handbook of Latvian Language]. Rīga: Latviešu valodas ağentūra. Retrieved from: http://valodasrokasgramata. lv/ (in Latvian).

Joas, H., Beckert, J. (2001). Action Theory. In: Jonathan H. Turner (Ed.), Handbook of Sociological Theory. New York: Kluwer Academic, pp. 269-285.

Kapoun, J. (1998). Teaching undergrads WEB evaluation: A guide for library instruction. Retrieved from: https://sites.ualberta.ca/ dmiall/Brazil/kapoun.html.

Karnītis, E. (2004). Informācijas sabiedrïba - Latvijas iespējas un uzdrošināšanās [Information Society - Opportunities and Confidence of Latvia]. Rīga: Pētergailis. (in Latvian).

Kirkwood, A., \& Price, L. (2014). Technology-enhanced learning and teaching in higher education: what is 'enhanced' and how do we know? A critical literature review. In: Learning, Media and Technology, 39(1), pp. 6-36.

Laumane, B. (Ed.) (1999). Latviešu valodas dialektu atlants. Leksika. [Atlas of the Latvian Dialects. Vocabulary]. Rīga: Zinātne. 
Leikuma, L., Dundure V., Vulāne, A. (2017). Olūteñš. Latgalǐšu rokstu volūda 4. klasei. Elektroniskais muoceibu leidzeklis. [Olūteňš. Latgalian Written Language. Form 4. Digital Learning Tool.] Reiga: VISC. Retrieved from: https:/visc.gov.lv/vispizglitiba/saturs/ dokumenti/metmat/olutens_4kl_mac_lidz.pdf (in Latvian).

Skola2030. Valsts izglitibas satura centra (VISC) īstenotais projekts "Kompetenču pieeja mācỉbu saturā". [School 2030. The project „Approach of Competencies in Teaching/Learning Content", implemented by National Centre for Education (NCE)]. (2019). Retrieved from: https://www.skola2030.lv/ (in Latvian).

Stikute, E. (2011). Latviešu literatūras didaktika [Didactics of Latvian Literature]. Rīga: RaKa. (in Latvian).

Vanags, P. (2019). Latviešu valodniecỉbas attistïba: informativi izglitojoša elektroniskā karte [Development of Latvian Linguistics: Informative Educational Digital Map]. Rīga: Latviešu valodas ağentūra. Retrieved from: http://www.lingvistiskakarte.lv (in Latvian).

Vulāne, A., Dundure, V., Matisāne, V. (2017). Olūteņš. Latgalǐšu rokstu volūda 4. klasei. Metodiskie ieteikumi [Olūteņš. Latgalian Written Language. Form 4. Methodological Recommendations.] Rīga: VISC. Retrieved from: https:/visc.gov.lv/vispizglitiba/saturs/ dokumenti/metmat/olutens_4kl_met_\%20ieteikumi.pdf (in Latvian).

\section{ABOUT THE AUTHORS}

Anna Vulāne, Dr. philol., is a leading researcher at the Latvian Language Institute of the University of Latvia, professor of the University of Latvia, expert in linguistics at the Council of Sciences of the Republic of Latvia.

Elita Stikute, Dr. paed., assotiated professor of the University of Latvia, teacher of Latvian language and Literature at Riga Centre Language school.

Research area - history of pedagogy, didactics of Literature, critical thinking approach in study and learning process. 